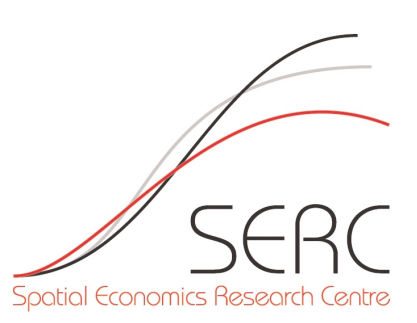

SERC DISCUSSION PAPER 22

\title{
Common and Spatial Drivers in Regional Business Cycles
}

Michael Artis (SERC, IPEG, University of Manchester, Swansea University)

Christian Dreger (DIW Berlin)

Konstantin Kholodilin (DIW Berlin)

April 2009 
This work was part of the research programme of the independent UK Spatial Economics Research Centre funded by the Economic and Social Research Council (ESRC), Department for Business, Enterprise and Regulatory Reform (BERR), the Department for Communities and Local Government (CLG), and the Welsh Assembly Government. The support of the funders is acknowledged. The views expressed are those of the authors and do not represent the views of the funders.

(C) M. Artis, C. Dreger and K. Kholodilin, submitted 2009 
Common and Spatial Drivers in Regional Business Cycles

\author{
Michael Artis*, Christian Dreger** \\ and Konstantin Kholodilin***
}

April 2009

* SERC, IPEG, University of Manchester, Swansea University

** DIW Berlin

*** DIW Berlin 


\begin{abstract}
$\underline{\text { Abstract }}$
We examine real business cycle convergence for 41 euro area regions and 48 US states. Results obtained by a panel model with spatial correlation indicate that the relevance of common business cycle factors is rather stable over the past two decades in the euro area and the US. Ongoing business cycle convergence often detected in cross-country data is not confirmed at the regional level. The degree of synchronization across the euro area is similar to that to be found for the US states. Thus, the lack of convergence does not seem to be an impediment to a common monetary policy.
\end{abstract}

JEL Classifications: E32, C51, E37

Keywords: Business cycle convergence, spatial correlation, spatial panel model 


\section{Introduction}

The degree of comovement of economic activity across states or regions is an issue of considerable importance to policy-makers. Asymmetric business cycles are often seen as inimical to the formation of a common currency area, although it has been argued that a common monetary policy in itself may reduce the cyclical asymmetry (Frankel and Rose 1998).

Economic theory does not provide a conclusive answer regarding the impact of economic integration on the synchronization of output fluctuations: see Backus, Kehoe and Kydland (1995) and Baxter and Kouparitsas (2005) and the issue remains an empirical one. Many authors have investigated the issue, as for example Artis and Zhang (1997), Kose, Otrok and Whiteman (2003), Artis, Krolzig and Toro (2004), Stock and Watson (2005) and Canova, Ciccarelli and Ortega (2006). Most of them have detected a tendency for national business cycles to converge during the integrative period of the second globalization from the 1960s. Artis and Okubo (2008) provide a long-run historical perspective which, by revisiting the era of the first globalization before the First World War, demonstrates a tendency for globalization to produce a high degree of synchronization in national business cycles.

While these findings are based on country data, little work has been done at the regional level. There is some indication that European monetary integration has boosted convergence, although the impact of national borders is quite strong (see Montoya and De Haan, 2007). While deeper trade integration exerts a positive effect on synchronisation, specialisation and exchange rate volatility appear to be the main sources of dispersion (Tondl and Traistaru-Siedschlag, 2006). Business cycles differ also across US states, see Owyang, Piger, and Wall (2005) as does the response to monetary policy (Carlino and De Fina, 1998 and 1999, Fratantoni and Schuh, 2003, Hanson, Hurst and Park, 2006). There is some evidence that synchronization has decreased since the late 1980s, implying that the US matches the optimum currency area criteria less well than in earlier times. The contradiction between what is 
commonly seen as being a highly successful monetary policy at the national level and this evidence of increasing asymmetry between regional cycles might be traced to a trade-off between national cycle volatility and regional synchronization (Partridge and Rickman, 2005).

Despite the attendant complications, exploiting the larger information set offered by the incorporation of regional data promises new insights. Regions tend to be more open to trade than countries and the degree of specialisation is higher than at the national level. If diverging trends cancel out in the aggregate, policy conclusions based on national evidence can be misleading. In addition, regional comovements may be caused not only by common business cycles, but also by non economic factors represented in the geographical map pattern; whilst this is linked to industrial structures and migration, it can also reflect habits, heritage and culture. Spatial spillovers have been largely neglected in previous studies, thereby creating omitted variable bias. A panel model allowing for spatial correlation is a convenient way to capture these effects. Here we apply such a model first to a set of US regional data points and, second, to a EuroaArea data set. The results of each model are then compared.

\section{Panel Models with Spatial Dependencies}

Dependencies along the regional dimension can be approximated by a spatial ARMA model

$$
y=\alpha W y+\beta X+\varepsilon+\theta W \varepsilon
$$

where $y$ is the endogeneous variable with observations from $n$ regions, $X$ a matrix of $k$ explanatory variables and $\varepsilon$ the error term (see Anselin, 2001). Spatial spillovers are captured by the introduction of spatial lags of the endogeneous variable or by spatial correlation in the error term. $W$ denotes a $n \times n$ matrix of spatial weights, with elements equal to 0 or 1 , depending on whether two regions share a common border (1) or not (0). Higher spatial lags can be embedded by defining $W$ in a cumulative form (Anselin, 2001). A row-standardized form of 
the matrix is often used to extract the mean of observations from contiguous regions. The Moran statistic

(2) $\quad m=\frac{y^{\prime} W y}{y^{\prime} y}$

is an overall measure of the strength of regional dependencies. The linkages may be driven by different forces, including business cycle comovements.

The model (1) refers to a pure cross sectional framework. To explore the impact of common drivers on regional business cycles, the time series dimension has to be added. This is done by estimating a panel model allowing for spatial effects: in this we follow the instructive leads given by Elhorst (2003) and Baltagi and Li (2006).

\section{Data and Results}

Data for 41 EU regions and 48 US states are exploited: see table 1 for the list of regions. Annual data on regional economic activity are available for the 1982-2007 period. Some regions are excluded for data reasons. Euro area series refer to GVA at 2000 prices reported by Cambridge Econometrics. Real GDP data for US states chained in 2000 dollars are from the BEA. State level data prior to 1991 are reconstructed using BEA quantity indexes. The analysis refers to the cyclical component of regional GDP. This is defined as a deviation from trend, where the latter is obtained by a HP filter. Following Ravn and Uhlig (2002), the smoothing parameter is set equal to 6.25. The results do not depend critically on this choice of filter: very similar estimates are obtained when GVA/GDP growth rates are used instead.

Figure 1 shows the rolling Moran coefficient, i.e. (2) calculated as an average over a moving window of eight years. The dependencies between EU regions were rather weak in the 1980s. Perhaps fostered by the European integration process, the correlation rose until the 
mid-1990s. After a decline during the new economy boom, regional spillovers regained importance in recent years. The initial correlation was quite high in US regions; after that, the dependencies decreased until the middle of the sample period. Subsequently, over more recent years, the strength of spillovers again increased gradually.

The Moran coefficient is an overall measure of regional dependencies. To explore the role of supraregional factors in this process, area wide business cycles are extracted as the first two principal components of regional cycles, as suggested by the information criteria (Bai and Ng, 2002). On average, the factors represent two thirds of cyclical output fluctuations, a share which declines towards the end of the sample. Regression results for different specifications are shown in table 2. The top panel of that table reports results for the whole sample period, the lower two for two successive sub-samples. The coefficients on the spatial lag and error terms for both data sets in the two periods examined confirm the relevance of spatial correlation in this context. The size and significance of the common cycle terms changes rather little through the period in either case, even if at the margin the size and significance of these terms has increased a little in the EU compared to the US.

\section{Conclusions}

Business cycle comovements are important in explaining regional output fluctuations. With the effect of spatial correlation taken care of in the estimates, as here, the parameters testifying to the presence of a common cycle appear robust across subperiods. The inclusion of spatial effects improves the model fit. Nevertheless, common business cycles do not account for a larger share of the regional economic evolution in more recent years. Thus the tendency towards a higher cyclical synchronization often found in cross- country panels cannot be confirmed at the regional level. To the extent that the degree of intra-national synchronization of 
business cycles appears much the same in the EuroArea as in the US, the potential for a successful monetary policy in the EuroArea is not compromised. 


\section{References}

Anselin, L. (2001): Spatial econometrics, in Baltagi, B.H. (ed.): A companion to theoretical econometrics, Malden, Blackwell, 310-330.

Artis, M., Krolzig, H.-M., Toro, J. (2004): The European business cycle, Oxford Economic Papers 56, 1-44.

Artis, M., Zhang, W. (1997): International business cycles and the ERM. Is there a European business cycle?, International Journal of Finance and Economics 2, 1-16.

Artis, M. and Okubo,T. (2008): Globalization and Business Cycle Transmission, CEPR Discussion Papers, No.7041.

Backus, D.K., Kehoe, P.J., Kydland, F.E. (1995): International business cycles. Theory and evidence, in Cooley, T. (ed.): Frontiers of business cycle research, Princeton University Press, Princeton, 331-356.

Bai, J.,Ng, S. (2002): Determining the number of factors in approximate factor models, Econometrica, 70, 191-221.

Baltagi, B.H., Li, D. (2006): Prediction in the panel data model with spatial correlation: the case of liquor, Spatial Economic Analysis 1, 175-185.

Baxter, M., Kouparitsas, M.A. (2005): Determinants of business cycle comovement: A robust analysis, Journal of Monetary Economics 52, 113-157.

Canova, F., Ciccarelli, M., Ortega, E. (2006): Similarities and convergence in G-7 cycles, Journal of Monetary Economics 54, 850-878.

Carlino, G., De Fina, R. (1998): The differential regional effects of monetary policy, Review of Economics and Statistics 80, 572-587.

Carlino, G., De Fina, R. (1999): The differential regional effects of monetary policy: Evidence from US states, Journal of Regional Science 39, 339-358.

Elhorst, J.P. (2003): Specification and estimation of spatial panel data models, International Regional Science Review 26, 244-268.

Elhorst, J.P. (2009): Spatial panel data models, in: Fischer, M., Getis, A. (eds): Handbook of Applied Spatial Analysis, Chapter 2.

Frankel, J.A., Rose A.K. (1998): The endogeneity of the optimum currency area criteria, Economic Journal 108, 1009-1025.

Frantantoni, M., Schuh, S. (2003): Monetary policy, housing, and heterogeneous regional markets, Journal ofMoney, Credit and Banking 35, 557-589.

Hanson, M.S., Hurst, E., Park, K.Y. (2006): Does monetary policy help least those who need it most?, Wesleyan University Economic Working Papers 2006-006. 
Kose, M.A., Otrok, C., Whiteman, C.H. (2003): International business cycles. World, region and country-specific factors, American Economic Review 93, 1216-1239.

Montoya, L.A., De Haan, J. (2007): Regional business cycle synchronization in Europe?, Bruges European Economic Research Paper 11, International Economics and Economic Policy, forthcoming.

Owyang, M.T., Piger, J., Wall, H.J. (2005): Business cycle phases in US states, Review of Economics and Statistics 87, 604-616.

Partridge, M.D., Rickman, D.S. (2005): Regional cyclical asymmetries in an optimal currency area: An analysis using US state data, Oxford Economic Papers 57, 373-397.

Ravn M, Uhlig H. (2002): On adjusting the HP-filter for the frequency of observations, Review of Economics and Statistics 84, 371-375.

Stock, J.H., Watson, M.W. (2005): Understanding changes in international business cycle dynamics, Journal of the European Economic Association 3, 968-1006.

Tondl, G., Traistaru-Siedschlag, I. (2006): Regional growth cycle synchronisation within the euro area, Economic and Social Research Institute, Dublin, Working Paper 173. 
Table 1: Euro area and US regions

\section{A Euro area regions}

Belgium: Brussels, Vlaams Gewest, Wallonne. Germany: Baden-Wuerttemberg, Bayern, Bremen, Hamburg, Hessen, Niedersachsen, Nordrhein-Westfalen, Rheinland-Pfalz, Saarland, Schleswig-Holstein. Spain: Noroeste, Communidad de Madrid, Centro, Este, Sur. France: Île de France, Bassin Parisien, Nord-Pas-de-Calais, Est, Ouest, Sud-Ouest, Centre-Est, Méditerranée. Italy: Nord Ovest, Nord Est, Centro, Sud, Isole. Luxembourg: Luxembourg. Netherlands: Nord-, Oost-, West-, Zuid-Nederland. Austria: Ost-, Sued-, Westoesterreich. Portugal: Continente.

B US regions

All states excluding Alaska and Hawaii 
Table 2: Components of regional output growth 1982-2007

\begin{tabular}{|l|c|c|c|c|}
\hline \multirow{2}{*}{} & \multicolumn{2}{|c|}{ Euro area } & \multicolumn{2}{c|}{ US } \\
\hline Factor 1 & $\begin{array}{c}0.131 \\
(14.37)\end{array}$ & $\begin{array}{c}0.177 \\
(20.15)\end{array}$ & $\begin{array}{c}0.118 \\
(12.72)\end{array}$ & $\begin{array}{c}0.188 \\
(17.24)\end{array}$ \\
\hline Factor 2 & $\begin{array}{c}0.035 \\
(2.67)\end{array}$ & $\begin{array}{c}0.047 \\
(2.70)\end{array}$ & $\begin{array}{c}0.010 \\
(0.76)\end{array}$ & $\begin{array}{l}0.016 \\
(0.769)\end{array}$ \\
\hline Spatial lag & $\begin{array}{c}0.262 \\
(7.32)\end{array}$ & & 0.371 & $(11.30)$ \\
\hline Spatial error & & 0.258 & & 0.362 \\
& 0.429 & 0.430 & 0.415 & 0.417 \\
\hline R-squared & 3400.27 & 3400.26 & 3802.34 & 3802.93 \\
\hline Log likelihood & & & & \\
\hline
\end{tabular}

1982-1994

\begin{tabular}{|l|c|c|c|c|}
\hline & \multicolumn{2}{|c|}{ Euro area } & \multicolumn{2}{c|}{ US } \\
\hline Factor 1 & $\begin{array}{c}0.128 \\
(9.73)\end{array}$ & $\begin{array}{c}0.174 \\
(12.98)\end{array}$ & $\begin{array}{c}0.107 \\
(8.62)\end{array}$ & $\begin{array}{c}\text { U.194 } \\
(12.00)\end{array}$ \\
\hline Factor 2 & $\begin{array}{c}0.033 \\
(1.94)\end{array}$ & $\begin{array}{c}0.044 \\
(1.94)\end{array}$ & $\begin{array}{c}0.020 \\
(1.20)\end{array}$ & $\begin{array}{c}0.036 \\
(1.26)\end{array}$ \\
\hline Spatial lag & $\begin{array}{c}0.264 \\
(5.22)\end{array}$ & & $\begin{array}{c}0.447 \\
(10.34)\end{array}$ & \\
\hline Spatial error & & 0.269 & & 0.428 \\
& & $(5.72)$ & 0.486 & 0.483 \\
\hline R-squared & 0.399 & 0.397 & 1907.90 & 1905.50 \\
\hline Log likelihood & 1578.46 & 1577.35 & $1902)$ \\
\hline
\end{tabular}




\begin{tabular}{|l|c|c|c|c|}
\hline \multirow{2}{*}{ Factor 1 } & \multicolumn{2}{|c|}{ Euro area } & \multicolumn{2}{c|}{ US } \\
\hline Factor 2 & $\begin{array}{c}0.143 \\
(11.64)\end{array}$ & $\begin{array}{c}0.186 \\
(18.34)\end{array}$ & $\begin{array}{c}0.137 \\
(9.03)\end{array}$ & $\begin{array}{c}0.189 \\
(11.50)\end{array}$ \\
\hline Spatial lag & $\begin{array}{c}0.061 \\
(1.81)\end{array}$ & $\begin{array}{c}0.080 \\
(1.80)\end{array}$ & $\begin{array}{c}-0.021 \\
(0.79)\end{array}$ & $\begin{array}{c}-0.028 \\
(0.791)\end{array}$ \\
\hline Spatial error & $\begin{array}{c}0.231 \\
(4.48)\end{array}$ & $\begin{array}{c}0.279 \\
(5.61)\end{array}$ & \\
\hline R-squared & 0.529 & 0.527 & 0.342 & 0.285 \\
\hline Log likelihood & 1939.95 & 1935.61 & 1902.72 & 1900.52 \\
\hline
\end{tabular}

Note: 41 EU regions, 48 US states. Regional GVA and GDP growth rate explained by first two principal components (factor 1, factor 2), spatial lags and spatial errors of first order. Panel regression with fixed regional effects, $t$-values in parantheses. R-squared adjusted. 
Figure 1: Rolling Moran coefficient

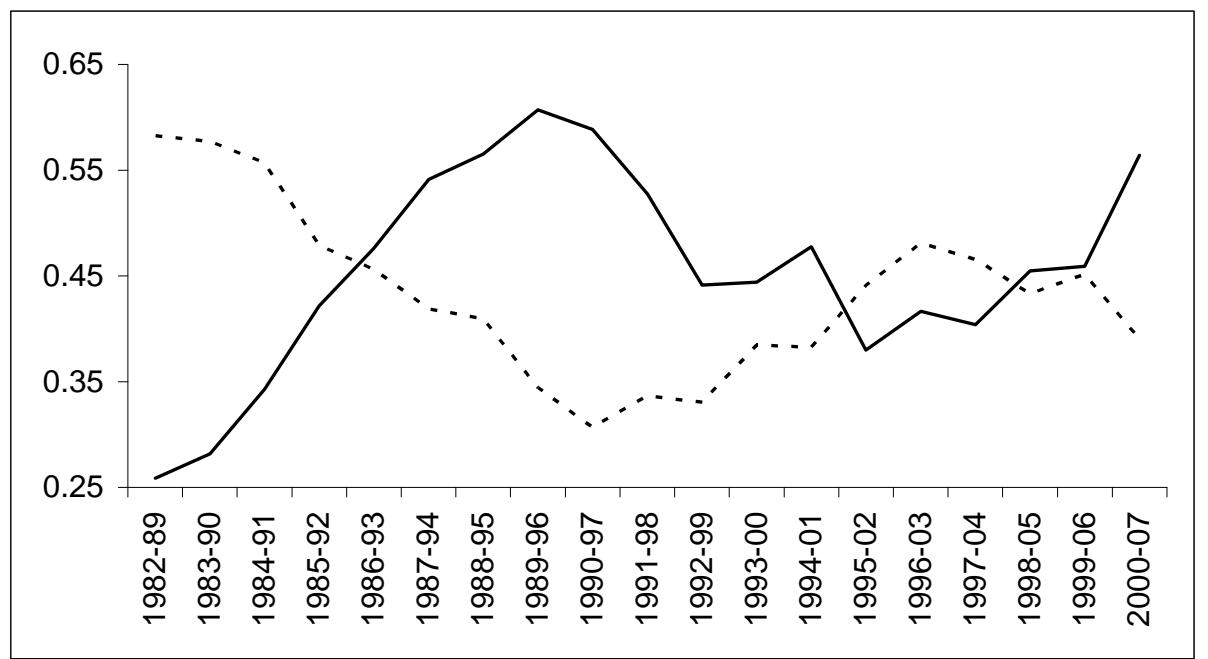

Note: Average Moran coefficient for first order spatial autocorrelation between EU and US (dashed line) regions. 


\section{BERR}

\section{Spatial Economics Research Centre (SERC)}

London School of Economics

Houghton Street

London WC2A 2AE

Tel: 02078523565

Fax: 02079556848

Web: www.spatialeconomics.ac.uk

SERC is an independent research centre funded by the Economic and Social Research Council (ESRC), Department for Business, Enterprise and Regulatory Reform (BERR), the Department for Communities and Local Government (CLG) and the Welsh Assembly Government. 